\title{
Gemological ABSTRACTS
}

\section{EDITOR}

A. A. Levinson

University of Calgary

Calgary, Alberta, Canada

REVIEU BOARD

Jo Ellen Cole

Vista, California

Claudia D'Andrea

GIA Gem Laboratory, Carlsbad

Vladislav Dombrovskiy

GIA Gem Laboratory, Carlsbad

Michelle Walden Fink

GIA Gem Laboratory, Carlsbad

R. A. Howie

Royal Holloway, University of London

Alethea Inns

GIA Gem Laboratory, Carlsbad

Taijin Lu

GIA Research, Carlsbad

Wendi M. Mayerson

GIA Gem Laboratory, New York

Kyaw Soe Moe

GIA Gem Laboratory, Carlsbad

Keith A. Mychaluk

Calgary, Alberta, Canada

Joshua Sheby

GIA Gem Laboratory, New York

James E. Shigley

GIA Research, Carlsbad

Russell Shor

GIA, Carlsbad

Maha Tannous

GIA Gem Laboratory, Carlsbad

Rolf Tatje

Duisburg University, Germany

Christina Taylor

Boulder, Colorado

Sharon Wakefield

Northwest Gem Lab, Boise, Idaho

\section{COLORED STONES AND ORGANIC MATERIALS}

Classification of amber based on thermal analysis. E. Ragazzi, G. Roghi, A. Giaretta, and P. Gianolla, Thermochimica Acta, Vol. 404, No. 1/2, 2003, pp. 43-54.

It is difficult to determine the chronological age of fossil resins by chemical analysis alone, because amber samples of the same geologic age may have experienced different chemical reactions and temperatures during their fossilization. This study was undertaken to evaluate the possibility of classifying ambers by thermal analysis techniques. Thermal analysis involves the detection of small changes in the weight of a sample as it is subjected to controlled heating. Two methods-thermogravimetric (TG) and differential thermogravimetric (DTG) analyses-were used for 13 amber samples of various ages (present day to Triassic, 225 million years ago) and eight geographic origins. Using the DTG method, all samples exhibited a main weight-loss event at about $400^{\circ} \mathrm{C}$, but the exact temperature varied according to age (i.e., the temperature increased linearly with age). The results suggest that thermal analysis provides an additional way to characterize fossil resins.

JES

Death and taxes: The case of the depletion of pearl oyster beds in sixteenth century Venezuela. A. Romero, Conservation Biology, Vol. 17, No. 4, 2003, pp. 1013-1023.

Commercial pearling began off the coast of what is today Venezuela when Christopher Columbus brought a number of pearls back to Spain from his third voyage to the New World in 1498. From 1508 to 1520 , large numbers of Lucayan Indians from the Bahamas were taken by Spanish settlers to Cubagua, an island off the Venezuelan coast, to work as pearl divers. The Lucayans were prized for their deep-diving skills. By 1518, so

This section is designed to provide as complete a record as practical of the recent literature on gems and gemology. Articles are selected for abstracting solely at the discretion of the section editor and his reviewers, and space limitations may require that we include only those articles that we feel will be of greatest interest to our readership.

Requests for reprints of articles abstracted must be addressed to the author or publisher of the original material.

The reviewer of each article is identified by his or her initials at the end of each abstract. Guest reviewers are identified by their full names. Opinions expressed in an abstract belong to the abstracter and in no way reflect the position of Gems \& Gemology or GIA

(C) 2003 Gemological Institute of America 
many Lucayans had been forced from the Bahamas that the islands were left nearly deserted. The divers worked six per boat, dawn to dusk. In one or two weeks, each boat would typically harvest some 35,000 oysters from depths of $15-22 \mathrm{~m}$.

In 1515, the Spanish government began keeping precise tax records and recording pearl production from the area. That year saw the equivalent of $100 \mathrm{~kg}$ of pearls harvested. Production increased greatly after 1520, when the Spanish military established a fort at Cubagua to secure the pearling area and the town of Nueva Cádiz. Harvesting of oysters increased dramatically over the next several years, peaking at $1,650 \mathrm{~kg}$ in 1527 . Production, however, fell off just as sharply afterward. To revive it, Spanish King Charles V approved the use of dredges to work the pearl beds. By 1531, depletion of the oyster beds was well underway. Production had fallen to about one-third of the peak, causing the local administration to place severe restrictions on pearling activities. This is possibly the first attempt at conservation in modern history. Nevertheless, by 1539 the oyster beds were almost totally decimated and fewer than 50 people remained on the island; in 1543, the once-thriving colony was abandoned. Eventually, the habitat that had been dominated by the Pinctada imbricata pearl oyster was taken over by the stronger, non-pearlbearing turkey-wing mussel Arca zebra.

Time-resolved luminescence of $\mathrm{Cr}^{3+}$ in topaz $\mathrm{Al}_{2} \mathrm{SiO}_{4}(\mathrm{OH}, \mathrm{F})_{2}$. M. Gaft, L. Nagli, R. Reisfeld, G. Panczer, and M. Brestel, Journal of Luminescence, Vol. 102-103, 2003, pp. 349-356.

This article reports the study of various luminescence centers in natural topaz crystals (two colorless, four yellow, and one orange) using laser-induced time-resolved luminescence spectroscopy. With this method, various luminescence centers in minerals can be detected according to their unique decay times. In the colored samples with elevated $\mathrm{Cr}$ contents, the study showed evidence of $\mathrm{Cr}^{3+}$ and Cr-Cr pair centers. Radiation-induced centers also were discerned in a yellow sample and determined to be thermally unstable; these centers could possibly be related to $\mathrm{Mn}^{4+}$ and/or $\mathrm{V}^{2+}$ impurities.

\section{DIAMONDS}

Diamond-bearing dykes. M. Marx, Rough Diamond Review, No. 1, June 2003, pp. 21-24.

Diamonds are usually mined from primary kimberlite (or lamproite) pipes or from secondary deposits along rivers, beach terraces, or the sea bed. Although rare, dike deposits can also be important. Kimberlite dikes are found on all continents, but currently only four dike mines, all in South Africa, are in production. One of these is the Messina mine, where diamond-bearing kimberlite is being extracted at $\sim 700 \mathrm{~m}$ below the surface. When the Snap
Lake mine in Canada comes into production in a few years, dikes may produce $\sim 1.5$ to 2.0 million carats per year ( $1.5 \%$ of the world's supply of diamonds).

A dike network represents the deep root zone of a volcanic event that can be associated with the formation of a diamond-bearing pipe. If a pipe is completely eroded, the underlying dikes may remain along with their diamonds and indicator minerals (e.g., pyrope, Cr-diopside). However, kimberlite dikes are difficult to find because they are typically weathered, frequently buried beneath sand or other types of cover, and have relatively small surface expressions. Although they may form linear features up to several $\mathrm{km}$ in length, they are also very narrow (often $<1 \mathrm{~m}$ ). Underground mining - mostly by the "shrinkage stoping" method-is more efficient than open-pit mining because dikes are narrow and near vertical, so the latter would require excessive stripping ratios.

CT

Getting the most out of our diamonds: Namibia, De Beers and the arrival of Lev Leviev. M. Boer and R. Sherbourne, Institute of Public Policy Research, Briefing Paper No. 20, September 2003, 20 pp., www.ippr.org.na.

Although its diamond production is relatively small in volume (1.7 million carats in 2002), Namibia is the world's sixth largest producer by value, at $\$ 472$ million in 2002 . The average value of Namibian diamonds is $\sim 280$ per carat, nearly twice that of the next highest value producer (Angola). De Beers and predecessors have controlled Namibia's diamond production for over 80 years, but new players in the diamond market may offer the country a better return on its resources. The future of Namibia's diamond production lies in the seabeds just offshore. Currently over half (55\% in 2002) of the country's output is extracted offshore. The government is also trying to encourage diamond cutting to increase employment. However, labor costs are not competitive with low-wage nations like China and India.

The Namibian government and De Beers together mine and manage the vast majority of the country's diamond resources through a 50-50 corporation called Namdeb. Namdeb, however, issues no public reports, so it is difficult to ascertain whether the government is getting the most out of its diamonds. An alternative may be offered by Lev Leviev, an Israeli industrialist who has already opened a diamond-cutting operation there. He became involved in Namibia's diamonds through an interest in the financially troubled Namco Corp., which formerly operated an offshore mining concession. Namibia has done well through its partnership with De Beers, and Leviev remains a relatively new, unknown competitor.

$R S$

A guide to rough diamond classifications. Rough Diamond Review, No. 1, June 2003, pp. 9-12.

The classification of diamond rough provides a framework for valuing and trading stones. For gem diamonds, the De 
Beers Central Selling Organisation (CSO) uses several value-classifying factors: estimated yield (the weight of the polished product as a percentage of the rough weight), processing costs, and quality (i.e., size, color, and clarity factors). Traders and manufacturers have developed their own categories to describe and value rough diamonds. However, all classifications are based on four commonly recognized terms and descriptors:

- Size: Most smaller stones are screened and assigned to a sieve size or class, based on either the DTC (De Beers) or Antwerp (Christensen) sieve-size classification. Stones above $0.66 \mathrm{ct}$ are weighed individually, as accuracy of weight is critical to valuation.

- Quality: Quality is judged with back-lighting. The quantity, position, nature, and severity of inclusions dictate a stone's quality. Diamond qualities are broadly grouped into one of the following classifications: Gem, Near Gem, Rejections, and Industrial (or Bort). Subcategories also have been established (i.e., first, second, third, and fourth qualities).

- Type: Type primarily encompasses shape, which also reflects a relationship with yield and the manufacturing processes required. The six principal types are sawables, makeables, macles, flats, chips, and clivage.

- Color: Color is judged by placing rough diamonds on a white surface without any back-lighting. The color of most diamonds falls in the range of colorless to yellow or colorless to brown; other color terms include white, light brown, Cape, and fancy. Each group has subcategories.

In general, all diamond deposits contain most of the quality and type categories in varying proportions, but not all color groups. Industrial diamonds are classified differently.

Indicator mineral and till geochemical dispersal patterns associated with the Ranch Lake kimberlite, Lac de Gras region, NWT, Canada. M. B. McClenaghan, B. C. Ward, I. M. Kjarsgaard, B. A. Kjarsgaard, D. E. Kerr, and L. A. Dredge, Geochemistry: Exploration, Environment, Analysis, Vol. 2, No. 4, 2002, pp. 299-320.

Diamond indicator minerals in glacial till collected around the large (12.4 ha; 31 acres) Ranch Lake kimberlite in the Lac de Gras region, NWT, Canada, define a spectacular dispersal train according to the length $(70 \mathrm{~km})$, narrow ("ribbon") shape, and abundance of indicator minerals (thousands of mineral grains in a $10 \mathrm{~kg}$ till sample). Crdiopside and pyrope are the most abundant indicator minerals, while chromite is less abundant, and Mg-ilmenite is rare; most indicator minerals occur in the $0.25-0.50 \mathrm{~mm}$ fraction of the till. At its head, the train is $500 \mathrm{~m}$ wide and gradually widens to $2 \mathrm{~km}$ at $20 \mathrm{~km}$ down-ice. The lateral edges of the train are sharply defined by the presence or absence of the indicator minerals in the till. Patterns for Cr-diopside and pyrope abundances are similar, and concentrations reach their highest levels $15-20 \mathrm{~km}$ down-ice. The location of these high concentrations is unusual, because most studies indicate that the highest concentrations of indicator minerals in till occur immediately down-ice from the kimberlite, after which there is a gradual decrease due to dilution. The great length of the dispersal train suggests it was formed by a single ice flow event.

Not all kimberlites in the Lac de Gras region have indicator mineral dispersal trains, and of those that do, few are as well developed or as well preserved as that at Ranch Lake. Nevertheless, the use of till dispersal patterns is popular for diamond exploration in the glaciated terrains of Canada because of the effectiveness, versatility (both regional- and local-scale surveys), and relatively low cost.

$A A L$

Laser processing of diamonds. J. Chapman, Rough Diamond Review, No. 1, June 2003, pp. 25-28.

Modern diamond factories have replaced traditional handfashioning of diamonds with laser systems that can perform many steps in the cutting process with precision. The capital expenditure for a laser system specifically designed to process diamonds is high (US\$60,000-100,000), but there are numerous benefits, including high throughput rates, unattended operation, short training periods compared to traditional techniques, and insensitivity to crystal orientations. Most systems used for diamond processing employ a YAG laser with a beam diameter of 1-4 mm emitting at an infrared wavelength. The systems are supported by custom software for sawing, kerfing, bruting, and inscribing.

The advantages of lasers in each stage of the fashioning process are indisputable. For example, sawing with lasers can be achieved in any crystal direction, and bruting with lasers requires half the time of traditional bruting. However, there are occasional disadvantages. For example, during laser sawing diamonds may crack, especially those that are internally stressed, such as brown or pink stones. Additionally, after laser bruting, the girdle is sometimes slightly tapered and thus is unsuitable for the dops used in automatic polishing machines. In the future, the industry may adopt ultraviolet lasers, which recently have seen major developments in manufacture and reliability. UV lasers have the advantage of ablating (i.e., removing) diamond by a process of atomic disassociation rather than by thermal vaporization. This could decrease sawing weight loss to the range of $1-2 \%$, compared to the 4-5\% seen with current laser technology.

CT

Morphology of diamond crystals from the Bingara Range, northern New South Wales, Australia. J. D. Hollis, Australian Gemmologist, Vol. 21, No. 9, 2003, pp. 350-359.

The crystal morphology of 300 small (average $0.13 \mathrm{ct}$ ) euhedral diamonds selected from over 8,700 crystals from 
Mesozoic gravels at the Monte Christo prospect, Bingara, New South Wales, reflects progressive chemical corrosion of primary forms. Etching and resorption features, which in some cases result from a loss of more than $50 \%$ of the original size of the diamonds, were acquired during complex formational and eruption events. Many of the forms (illustrated in numerous line drawings) are those typical of kimberlitic and lamproitic diamonds worldwide, but some unusual features also are described. Some give evidence of their probable eruption histories in an unorthodox mobilebelt setting, far removed from cratons. $R A H$

The pressures and temperatures of formation of diamond based on thermobarometry of chromian diopside inclusions. P. Nimis, Canadian Mineralogist, Vol. 40, 2002, pp. 871-884.

Mineral inclusions in diamond have been used to estimate the pressure and temperature conditions of diamond formation in the earth's mantle. In most instances, this estimate requires that data be obtained from at least two syngenetic mineral phases in equilibrium. Finding diamonds with appropriate inclusion pairs is difficult, and there are additional challenges in collecting and interpreting the compositional data. In this article, the author uses a thermobarometry method that relies on just one inclusion phase (chromian diopside, a clinopyroxene), and he presents an analysis of published electron-microprobe data for more than 100 clinopyroxene inclusions in diamonds from worldwide occurrences. The results of this analysis appear to be consistent with estimates of mantle temperatures and pressures determined by other methods.

Use of this clinopyroxene thermobarometer may also have implications for diamond exploration strategies, since mantle-derived pyroxene recovered as an indicator mineral can be analyzed to see if there is evidence of a thermal or metasomatic event that occurred in the mantle which would have led to a resorption of diamond (thus indicating an unlikely target for diamond potential).

JES

Sierra Leone diamond sector financial constraints study. Prepared by Management Systems International under U.S. Agency for International Development Cooperative Agreement 636-A-003-00003, June 2003, 52 pp., www.peacediamonds.org (click on "Links and Publications").

Harnessing Sierra Leone's diamond wealth to benefit its citizens has been an elusive goal for three-quarters of a century. The country's diamond deposits, generally rich in larger, high-quality goods, are found in easily looted alluvial pockets spread across a wide swath of the nation. What is more problematic, nearly all the nation's commerce-especially diamonds-has been controlled by a coterie of Lebanese traders. And, tragically, the rebel group RUF used diamonds to help fund a brutal civil war that ended in 2002. Last year, an estimated US\$300-320 million in diamonds were extracted from Sierra Leone, with
$85-90 \%$ of that total either smuggled out or "legally" exported at grossly understated values to avoid taxes.

The U.S. Agency for International Development and the U.K. Department for International Development, in cooperation with the government of Sierra Leone, nongovernmental organizations, and local officials, are trying to overhaul the country's diamond production to finally accomplish more equitable distribution of its diamond wealth. This study, conducted by Chaim Even-Zohar (Tacy Ltd. Consultants, Ramat Gan, Israel), offers a set of solutions on how to tackle the massive hemorrhaging of diamonds and cash from Sierra Leone.

\section{Problems:}

1. The diamond areas are still unregulated. An estimated 300,000 diggers have returned to the alluvial fields, thwarting any efforts at control.

2. Many of these diggers are debt-bonded to local dealers and exporters, who acquire these diamonds for a fraction of their sales value.

3. Virtually all diamond business is conducted in cash, and money laundering occurs on a massive scale.

4. The small groups of exporters and dealers who control an estimated $80 \%$ of the trade all sell to affiliates in Antwerp, Switzerland, Dubai, or other markets. These groups also squeeze out competition and keep local prices artificially low, resulting in huge profits from sales in diamond centers.

5. The government is ill-equipped to deal with managing its diamond resources, and its banking system remains in a shambles.

\section{Recommendations:}

1. Invite major players (De Beers, Rio Tinto, etc.) to serve as marketing alternates to the local cartels that control most exports. This would promote competition and help protect small miners. Local cartels could not intimidate large multinationals.

2. Reform finance and credit systems to bring in capital and end the debt-bondage system that has existed for years. These reforms must be backed by large banks to ensure compliance and resist local pressures to maintain the status quo.

3. Establish paper trails on cash transactions to reduce the potential for money laundering.

4. Train locals in diamond valuation.

The report also reviews the history of Sierra Leone diamond production.

The significance of mineral inclusions in large diamonds from Yakutia, Russia. L. A. Taylor, M. Anand, P. Promprated, C. Floss, and N. V. Sobolev, American Mineralogist, Vol. 88, No. 5-6, 2003, pp. 912-920.

It is generally accepted that mineral inclusions in diamonds are syngenetic (i.e., formed contemporaneously and 
under the same conditions of temperature and pressure, and from the same genesis) with their diamond hosts. On the basis of this premise, these inclusions are considered pristine, as they have presumably been isolated since their encapsulation. Among the several applications of this concept is the assumption that the inclusions and their host diamonds are identical in age.

However, this article seriously questions the syngenetic relationship between diamonds and these inclusions, based on the interpretation of inclusion chemical data obtained with electron and ion microprobes. The inclusions used in this study, primarily garnets of harzburgitic paragenesis, were obtained from large (10-200 ct) diamonds from three kimberlites (Udachnaya, Mir, and Aikhal) in Yakutia. The most striking chemical feature of the garnet composition is the distribution pattern of their rare-earth elements, which is sinusoidal. These patterns are obtained from all harzburgitic garnets worldwide, both within and independent of diamonds, and are indicative of a complex origin for the garnets, including partial melting and metasomatic enrichment. Such events are believed to have occurred prior to their encapsulation in diamond. This result is taken as proof that basically all harzburgitic garnet inclusions are nonsyngenetic with their diamond hosts. If confirmed, these results may have significant ramifications for current concepts relative to conditions and age of diamond formation.

$A A L$

X-ray diamond recovery techniques. A. Clegg, Rough Diamond Review, No. 1, June 2003, pp. 14-17.

Diamond has physical and chemical properties that permit several potentially successful recovery techniques. These properties include a hardness of 10, a non-magnetic and hydrophobic nature (i.e., will not be wetted by water and will stick to grease), and a reasonably high specific gravity (3.52). Historically, this enabled recovery based on the use of grease tables and belts, and heavy-media separation. However, these methods were not suited to the arctic climates of the former Soviet Union where, starting in 1958, X-ray sorting machines were developed based on the fact that most diamonds will fluoresce when exposed to X-rays. Thus, when crushed rock or gravel containing diamonds passes through an X-ray beam, the diamonds can be detected by their fluorescence and subsequently recovered.

The first Soviet X-ray sorters were extremely crude and hazardous by today's standards (e.g., operators would hand pick any fluorescing particle off a belt and be exposed to the high-energy X-rays). Later automated processes improved not only in safety but also in security. Currently, the diamonds are separated from ore by a puff of compressed air (activated by a light-sensitive photomultiplier tube) that blows the diamond into a collection chamber. Modern diamond X-ray sorters are tailored for the type of ore being processed (e.g., small-sized stones, large tonnages, wet or dry ore), with recovery of over $98 \%$ of the diamonds.

\section{GEM LOCALITIES}

$\mathrm{CO}_{2}-\mathrm{H}_{2} \mathrm{~S}-\mathrm{COS}-\mathrm{S}_{8}-\mathrm{AlO}(\mathrm{OH})$-bearing fluid inclusions in ruby from marble-hosted deposits in Luc Yen area, North Vietnam. G. Giuliani, J. Dubessy, D. Banks, H. Q. Vinh, T. Lhomme, J. Pironon, V. Garnier, P. T. Trinh, P. V. Long, D. Ohnenstetter, and D. Schwarz, Chemical Geology, Vol. 194, No. 1-3, 2003, pp. 167-185.

Gem-quality rubies have been mined in the Luc Yen area of Vietnam since 1987. They are found in primary deposits hosted by Cambrian-age metasediments, or in associated placer deposits. In the former, ruby occurs in marble lenses interlayered with amphibolites within garnet-mica schists and gneisses. Typical associated minerals include phlogopite, dravite, graphite, pyrite, margarite, and calcite. These and other minerals can occur as inclusions in the rubies.

Twenty-five representative rubies were selected for fluid-inclusion analysis using microthermometry, Raman and infrared spectroscopy, and chemical analysis techniques. Primary and secondary fluid inclusions provided evidence of $\mathrm{CO}_{2}-\mathrm{H}_{2} \mathrm{~S}-\mathrm{COS}-\mathrm{S}_{8}-\mathrm{AlO}(\mathrm{OH})$-bearing fluids containing daughter minerals such as native sulfur and diaspore, but little water. The ruby is inferred to have grown from a $\mathrm{CO}_{2}$-rich and water-poor fluid that was at equilibrium with $\mathrm{Na}-\mathrm{Ca}-\mathrm{Cl}$ salts (in the form of evaporitic minerals). Aluminum was transported in this fluid at high temperatures and pressures (thought to be on the order of $500-600^{\circ} \mathrm{C}$ and $3-5 \mathrm{kbar}$ ) to form the ruby. There is no evidence that corundum mineralization involved the magmatic rocks exposed in the area. Ruby crystallized within the marble, which acted as a closed system.

JES

Geology of an amber locality in the Hukawng Valley, northern Myanmar. R. D. Cruickshank and K. Ko, Journal of Asian Earth Sciences, Vol. 21, No. 5, 2003, pp. 441-455.

Amber ("burmite") from the Hukawng Valley in northern Myanmar has been known since at least the 1st century $\mathrm{AD}$. It is currently being produced from Noije Bum, a hill located about $20 \mathrm{~km}$ southwest of the town of Tanai. This hill was first documented as a locality for amber in 1836, and it has remained the principal source in the country since that time. The two authors visited the site in April 2001. Based on geologic and fossil evidence, the rocks hosting the amber are Cretaceous in age (as opposed to a Tertiary age inferred by geologists who visited the locality between 1892 and 1930). The amber is found along one horizon (about $1 \mathrm{~m}$ thick) in a series of steeply dipping clastic sedimentary rocks. The deposit is being worked from an open pit by a small group of miners using manual methods.

The amber occurs as small discoid-shaped clasts ranging up to several centimeters in diameter. The clasts are 
oriented parallel to the bedding of the host rocks. There is little evidence that the shape of the amber clasts has been modified due to transport from another location. The amber is typically reddish brown, with various shades of yellow, orange, and red also occurring. These colors range from light to dark, and the material can vary from transparent to opaque. Insect fossils are found in the amber, but most are microscopic in size. The amber is thought to have been deposited along with fine clastic sediments along the floors and banks of tidal channels in a nearshore marine environment.

Genesis and gemmology of sapphires from the Nezametnoye deposit, Primorye region, Russia. A. Khanchuk, B. Zalishchak, V. Pakhomova, E. Odarichenko, and V. Sapin, Australian Gemmologist, Vol. 21, No. 9, 2003, pp. 369-375.

Research into inclusions in sapphires from a placer deposit at Nezametnoye in the Russian Far East is reported, together with a study on the heavy accessory minerals in the underlying gold-bearing granite porphyries. Other minerals found with the sapphires include zircon and spinel. This is the only deposit of gem-quality corundum, spinel, and zircon presently known in Russia.

The sapphire inclusions were identified as columbite, albite, zircon, Zn-bearing hercynite, rutile, and glass. Based on the compositions of these inclusions and on the unusual occurrence of corundum as an accessory in the granite porphyries, it is concluded that the placer sapphires originated from rare-metal pegmatites, greisens, and metasomatic rocks associated with the widespread Mesozoic granitic bodies in the area.

$R A H$

Horse-tail inclusions in demantoid garnet from Val Malenco, Italy. P. W. O. Hoskin, R. H. Grapes, H. Catchpole, and J. Klaudius, Journal of Gemmology, Vol. 28, No. 6, 2003, pp. 333-336.

Gem-quality demantoid garnets from the Malenco Valley, northern Italy, may contain fibrous hair-like inclusions. These inclusions were assumed to be byssolite (tremoliteactinolite) asbestos by analogy with Russian demantoids. However, X-ray powder diffraction analysis of the matrix material in which the garnets are found, as well as electron-microprobe analysis of the inclusions themselves, showed that both the matrix material and the fibrous inclusions are chrysotile (asbestiform serpentine).

Optical examination of the chrysotile inclusions in transmitted light revealed that they have a light green to brown color. Although the authors confirmed the presence of chromium $\left(0.03-0.84 \mathrm{wt} . \% \mathrm{Cr}_{2} \mathrm{O}_{3}\right)$ in their garnets-the primary cause of color in demantoid-they found no correlation between the intensity of the green color and $\mathrm{Cr}_{2} \mathrm{O}_{3}$ abundance. Instead, they believe that the color variations are related to the relative abundance of the green-brown chrysotile inclusions.

WMM
Iron-rich chrysoberyl from Kalanga Hill, Muyombe District, north-eastern Zambia. V. Žáček and S. Vrána, Neues Jahrbuch für Mineralogie Monatshefte, No. 12, 2002, pp. 529-540.

Abundant chrysoberyl has been found in a granitic pegmatite dike near the Zambia/Malawi border at the base of Kalanga Hill (6 km northeast of Muyombe). The pegmatite has sharp contacts against the granulite host rock. The dike has a roughly N-S strike, and is at least $30 \mathrm{~m}$ long and $30-50 \mathrm{~cm}$ wide. It is symmetrically zoned and consists mainly of quartz, feldspar, muscovite, and beryl. Accessory minerals include rutile, ixiolite, samarskite, microlite, and zircon.

Chrysoberyl is found in the intermediate zones, or adjacent to the quartz core, of the pegmatite. It forms either translucent yellow-green to green euhedral crystals up to $3 \mathrm{~cm}$ long, or slightly larger intergrown aggregates. Some crystals exhibit typical pseudohexagonal twinning. Electron-microprobe analyses show that the chrysoberyl has high iron concentrations (3.16-6.25 wt. $\% \mathrm{Fe}_{2} \mathrm{O}_{3}$ ). Values are given for the unit-cell parameters and the measured density $\left(3.72 \mathrm{~g} / \mathrm{cm}^{3}\right)$, but typical gemological properties (e.g., R.I.) are lacking. Data are presented to compare the chemical composition of this material with that of samples from other sources. At this locality, the authors propose that the chrysoberyl formed by reactions involving feldspar and beryl, or muscovite and beryl. JES

A new chrome chalcedony occurrence from Western Australia. M. J. Willing and S. M. Stocklmayer, Journal of Gemmology, Vol. 28, No. 5, 2003, pp. 265-279.

Chrome chalcedony, an ornamental rock first discovered in 1955 in Zimbabwe (where it is known commercially as mtorolite), has been found in the Newman area of Western Australia. The color, attributed to chromium ( 0.24 wt.\% $\mathrm{Cr}_{2} \mathrm{O}_{3}$ ), is a fairly uniform deep green (grading to brown when traversed by later quartz veinlets), but a banded texture and variations in the green color can be seen with transmitted light. This translucent material differs from chrysoprase in two ways: (1) $\mathrm{Ni}$ is the chromophore in the latter; and (2) chrysoprase occurs as late-stage fracture fillings, whereas this chrome chalcedony occurs as masses representing the silicification of serpentine.

The chemical composition is predominantly $\mathrm{SiO}_{2}$ (95.01 wt.\%), with minor amounts of $\mathrm{Al}, \mathrm{Fe}, \mathrm{Mg}, \mathrm{Cr}$, and $\mathrm{H}_{2} \mathrm{O}$ and traces of $\mathrm{Mn}$ and $\mathrm{Ni}$ (e.g., 0.01 wt. $\% \mathrm{NiO}$ ). Quartz and traces of talc and mogánite (a metastable silica polymorph) were identified in the chrome chalcedony by X-ray diffraction methods. The microcrystalline groundmass is composed $(90 \%)$ of individual silica grains about $0.02 \mathrm{~mm}$ in diameter; localized rosettes and micro-fans of radiating chalcedony about $0.5 \mathrm{~mm}$ in diameter also occur. Some opaque magnetite grains with the margins altered to hematite occur as inclusions. Gemological properties are within the range characteristic of chalcedony: R.I. $=1.539$, 
S.G. $=2.57, \mathrm{H}=\sim 7$, intense red under the Chelsea filter, and inert to long- and short-wave UV radiation. The UVVis, NIR, and Raman spectroscopic characteristics of this material are documented.

KSM

Origin of a dolomite-related jade deposit at Chuncheon, Korea. T-F. Yui and S-T. Kwon, Economic Geology, Vol. 97, No. 3, 2002, pp. 593-601.

Nephrite jade deposits may be divided into those associated with serpentinites and those associated with dolomitic rocks. Although most occurrences are hosted by serpentinites, the more significant deposits in terms of ore tonnage occur in the latter. The Chuncheon deposit, located in the north-central portion of the Republic of Korea, represents one of the largest deposits of nephrite jade in the world, with estimated reserves of 300,000 tonnes of ore, one-quarter of which is considered to be gem-quality. This study was undertaken to better understand the conditions of formation of nephrite in dolomitic rocks.

At the Chuncheon location, nephrite occurs in Precambrian dolomitic marble and amphibolite schist that were intruded by a late Triassic-age granite. The nephrite is found in lenses up to $1 \mathrm{~m}$ thick and several meters in length along the contact between the marble and the schist. It displays a waxy luster and ranges from greenish gray to yellowish green. The nephrite, along with chlorite and several calcium silicate minerals (i.e., diopside, grossular, tremolite), are products of the hydrothermal alteration of the dolomitic marble.

The authors present oxygen and carbon stable-isotope data for samples of dolomite and silicate minerals from the deposit and associated country rocks. Based on these data and field observations, they suggest that the nephrite formed as the result of a metasomatic reaction involving fluid circulation at the contact between the marble and the schist. Formation of the deposit postdated late Triassic regional metamorphism of the area. The fluid involved in the metasomatism was of meteoric origin, and its regional circulation may have been induced by the intrusion of the nearby granite. The authors compare the geology and genesis of this deposit with that of the serpentinite-related Fengtien nephrite occurrence in Taiwan.

JES

Pink sapphire from southern Kerala, S. India: Implications on India-Madagascar correlation within Gondwana assembly. M. Santosh, R. Katori, S. Yoshikura, S. Higashi, and A. K. Salim, Gondwana Research, Vol. 5, No. 4, 2002, pp. 894-901.

Southern Kerala and the adjacent state of Tamil Nadu are historically important regions for gem production in southern India. A wide variety of gems-including beryl, chrysoberyl, corundum, garnet, quartz, spinel, topaz, and zircon-are found in primary deposits (mainly in pegmatites emplaced in granulite facies metamorphic rocks), or in associated alluvial deposits. Pink sapphire is found at
Melankode near Balaramapuram, and at Rose Mala near Tenmala. Electron-microprobe data indicate that the pink sapphire is nearly pure $\mathrm{Al}_{2} \mathrm{O}_{3}$ (98.43-99.48 wt.\%). $\mathrm{Cr}_{2} \mathrm{O}_{3}$ and $\mathrm{FeO}$ are each present in amounts up to $0.12 \mathrm{wt} \%$. Abundant $\mathrm{CO}_{2}$-rich fluid inclusions occur in the sapphires.

The estimated temperatures of formation of the Melankode pegmatite are in the $650-750^{\circ} \mathrm{C}$ range. The crystallization age of the pegmatite (based on $\mathrm{U}-\mathrm{Pb}$ and $\mathrm{Pb}-\mathrm{Pb}$ dating of gem zircons) has been calculated by others to be about 513 million years (My), whereas granulitefacies metamorphism in the same region is dated at about 540 My. Thus, pegmatite emplacement postdated the main period of granulite metamorphism. Both the pegmatite formation and regional metamorphism occurred during the Pan-African Orogeny (a geologic event beginning about $600 \mathrm{My}$ that led to the assembly of the Gondwana supercontinent).

Pink sapphires from these two Indian deposits are similar to material from a number of localities in southern Madagascar (Betroka, Ilakaka, Andranondambo), as well as from the Ratnapura district in Sri Lanka. These occurrences are cited by the authors as additional evidence for the juxtaposition of southern Madagascar, Sri Lanka, and southern India when these areas were brought together as part of Gondwana. Gem deposits in all three areas are within or closely proximal to a regional shear zone that extended at the time across Madagascar, southern India, and Sri Lanka, and terminated in Antarctica.

Pressure, temperature and fluid conditions during emerald precipitation, southeastern Yukon, Canada: Fluid inclusion and stable isotope evidence. D. Marshall, L. Groat, G. Giuliani, D. Murphy, D. Mattey, T. S. Ercit, M. A. Wise, W. Wengzynowski, and W. D. Eaton, Chemical Geology, Vol. 194, No. 1-3, 2003, pp. 187-199.

In 1998, emeralds were discovered at the Crown showing, located $7 \mathrm{~km}$ north of Fire Lake in southeastern Yukon. At this site, emerald mineralization occurs within muscovitetourmaline alteration zones (up to $1.5 \mathrm{~m}$ thick) adjacent to quartz-tourmaline veins that crosscut metavolcanic rocks of Devonian-Mississippian age. Eight distinct emerald zones within a few hundred square meters have been mapped on the property. The emerald crystals reach $4 \mathrm{~cm}$ in length; they are of good color with up to 7,816 ppm chromium. They contain abundant fluid inclusions, mostly along healed fractures, and some mineral inclusions (including tourmaline, calcite, quartz, zircon, scheelite, and sulfide minerals).

Analysis of the primary fluid inclusions (and using stable-isotope data) suggests that emerald precipitation took place from $\mathrm{H}_{2} \mathrm{O}-\mathrm{CO}_{2}-\mathrm{CH}_{4}\left( \pm \mathrm{N}_{2}, \mathrm{H}_{2} \mathrm{~S}\right)$-bearing saline brines at temperatures of $365-498^{\circ} \mathrm{C}$ and pressures of 700-2,250 bars (corresponding to burial depths of 2 to 7 $\mathrm{km})$. Emerald deposits are generally formed when geologic 
conditions bring together $\mathrm{Cr}$ and $\mathrm{Be}$. At this site, $\mathrm{Cr}$ is thought to have originated locally from mafic and ultramafic rocks during hydrothermal alteration, while Be is most likely derived from a nearby (within $600 \mathrm{~m}$ ) granite intrusion of Cretaceous age.

JES

Some lesser known Australian opals. G. Browne, Gemmologie: Zeitschrift der Deutschen Gemmologischen Gesellschaft, Vol. 51, No. 2-3, 2002, pp. 97-106.

Australia produces a range of lesser-known opals, of minor economic significance, that display properties and features of interest to gemologists and collectors. A selection of six such opals is described in this article. (1) Opal "pineapples" are found rarely, and only in the White Cliffs opal field, western New South Wales (NSW). They are pineapple-shaped opal pseudomorphs after an unidentified precursor that consisted of radiating clusters of monoclinic crystals. (2) Volcanic opal with play-of-color occurs as cavity fillings in amygdaloidal basalts, or as nodules in associated soils, near Tintenbar, northeastern NSW; this opal tends to craze. (3) Opal with and without play-of-color occurs as veinlets in metamorphic rocks near Coolgardie, Western Australia (WA). Although mined on a small scale in the 1960s, very little is known about this deposit or its opal. (4) Matrix opal, "cream" to gray in color, is found at Andamooka, South Australia, where it impregnates and partly replaces limestone cobbles and boulders. (5) Opal-infiltrated "thunder eggs" occur in the Upper Tweed River valley, northeastern NSW. In addition to play-of-color opal, the thunder eggs may be filled with common opal and chalcedony. (6) Facetable common opal of note occurs in two localities: "Sun" opal from Minyon Falls, NSW, is transparent and yellow to "amber" in color; the best specimens of yellowish green to brown "siliciophite" (opalized chrysotile asbestos) are found at Lionel, WA.

MWF

Spectroscopic studies of spessartine from Brazilian pegmatites. S. G. Eeckhout, C. Castañeda, A. C. M. Ferreira, A. C. S. Sabioni, E. de Grave, and D. C. L. Vasconcelos, American Mineralogist, Vol. 87, No. 10, 2002, pp. 1297-1306.

Mössbauer and FTIR spectra were acquired for spessartinealmandine garnets collected from three granitic pegmatites in Brazil to provide further information on garnet crystal chemistry. The garnets were sampled from the complex zoned Alto Mirador dike near Acarí in Rio Grande do Norte, and simple zoned dikes at two localities in Minas Gerais-Escondido near Conselheiro Pena, and Poaiá near São José da Safira. The garnets from these two kinds of pegmatites displayed different chemical compositions in terms of $\mathrm{Fe}, \mathrm{Mg}$, and $\mathrm{Ca}$ contents. For the Alto Mirador samples, both $\mathrm{Fe}^{2+}$ and $\mathrm{Fe}^{3+}$ were found to be present. A comparable $\mathrm{Fe}^{2+} / \mathrm{Fe}^{3+}$ ratio for all the samples from this pegmatite implies they formed under similar condi- tions. In contrast, no $\mathrm{Fe}^{3+}$ was detected in the garnets collected from the two simple pegmatites. These chemical differences were attributed to different magmas that produced the pegmatites.

Although absorptions due to molecular $\mathrm{H}_{2} \mathrm{O}$ were not present in the infrared spectra of any of the garnet samples, several features due to hydroxyl $(\mathrm{OH})$ were detected. The authors concluded that hydrogen incorporation in these garnets resulted from the substitution of $\left(\mathrm{O}_{4} \mathrm{H}_{4}\right)^{4-}$ for $\left(\mathrm{SiO}_{4}\right)^{4-}$.

JES

\section{INSTRUMENTS AND TECHNIQUES}

Cathodoluminescence of diamonds. W. Taylor, Rough Diamond Review, No. 1, June 2003, pp. 38-42.

Diamond emits visible light of various wavelengths when bombarded with a beam of electrons; this is known as cathodoluminescence (CL). CL is of practical importance in the study of both natural and synthetic diamonds, as it provides insight into their growth history and reveals radiation damage, lattice deformations, and impurity distributions. The two basic types of instrumentation used for viewing CL are the luminoscope (an attachment for an optical microscope) and the electron microscope. A spectrophotometer may be added to record spectra as a function of wavelength. Such spectral information is essential for determining the optical centers responsible for CL emissions. Photoluminescence (PL) spectroscopy using a Raman microspectrometer can provide equivalent information. CL imagery and CL or PL spectroscopy have been used to document more than 100 luminescence bands and optical centers in diamond. At present, satisfactory explanations exist for only a handful of those detected; these include explanations for CL emissions associated with synthetic growth, radiation damage, nitrogen-related optical centers, and platelets.

CT

A compilation of infrared absorption spectra of some specific gemstones as an aid to their identification. S. Fernandes, M. Khan, and G. Choudhary, Australian Gemmologist, Vol. 21, No. 9, 2003, pp. 361-367.

A compilation is presented of infrared absorption spectra for specific gemstones, all of which appear similar in color but otherwise display distinct properties. Using the transmission mode of an FTIR spectrometer, the authors recorded spectra for some 25 samples of each gem species examined, bearing in mind the variation in properties to be expected in anisotropic gem minerals with orientation. The aim is to provide "fingerprint" absorption patterns that allow gemstones of a similar color to be distinguished from one another (and, in some cases, natural stones from synthetics). Tables are presented with the characteristic IR spectra for blue, green, yellow, red, and colorless stones. No attempt is made to specify the causes for the various absorption bands.

$\mathrm{RAH}$ 
Identification of B jade by Raman spectroscopy. E. Zu, D. Chen, and P. Zhang, Spectroscopy and Spectral Analysis, Vol. 23, No. 1, 2003, pp. 64-66 [in Chinese with English abstract].

Infrared absorption spectroscopy is one of the most widely used methods for identifying polymer-impregnated jadeite (B-jade). However, with this technique it is difficult to locate the exact areas within a stone that contain the impregnated materials. These authors used Raman spectroscopy to overcome this deficiency inherent in the IR technique.

Four types of filling materials (paraffin wax, paraffin oil, AB [acrylate-epoxy] glue, and epoxy resins) in bleached and polymer-impregnated jadeites were identified using Raman spectroscopy. Their characteristic peaks were located in two ranges: $1700-1100 \mathrm{~cm}^{-1}$ and $3100-2800 \mathrm{~cm}^{-1}$. The four strongest peaks of both the AB glue and epoxy resins are related to phenyl. The 1609 and $1116 \mathrm{~cm}^{-1}$ peaks are assigned to the C-C stretching mode, while the peaks at 3069 and $1189 \mathrm{~cm}^{-1}$ are attributed to the $\mathrm{C}-\mathrm{H}$ in-plane bending mode and $\mathrm{C}-\mathrm{H}$ stretching mode, respectively. Paraffin wax and paraffin oils displayed strong peaks at 2882 and $3848 \mathrm{~cm}^{-1}$, respectively.

$T L$

\section{JEWELRY HISTORY}

Mineralogy and alteration of Chinese archaic jade artifacts. H.-H. Tsien and J.-N. Fang, Western Pacific Earth Sciences, Vol. 2, No. 3, 2002, pp. 239-250.

Archaic tremolite jade artifacts unearthed from various cultural sites in China show very different sedimentary structures and textures. On jade artifacts that suffered alteration due to weathering, powder X-ray diffraction patterns of whitened zones and unaltered regions are identical, suggesting that the alteration did not change the mineral composition. However, scanning electron microscopy shows that in unaltered areas the microstructure is compact and formed of platy crystals, whereas the whitened areas are porous and formed of acicular crystals. The authors attribute the alteration to degradation or aggrading crystallization in wet or humid conditions.

RAH

\section{JEWELRY RETAILING}

He turned web site in the rough into online jewel. $B$. Acohido, USA Today, October 20, 2003, p. 5B.

This article profiles Mark Vadon, founder and CEO of Blue Nile, the Internet diamond and jewelry retailer. In 1999, Vadon was a consumer products consultant at Bain \& Co. when he visited a retail jeweler to buy a diamond engagement ring. He wanted information about diamonds, but the retailer advised him to buy a diamond that "spoke" to him. After checking for diamond information on the Internet, he forged a deal with a small outfit then known as internetdiamonds.com. At the height of the "dot.com" boom, he raised $\$ 57$ million to transform the small company into Blue Nile.

His marketing strategy: aim at men, keep profit margins low, and provide lots of information "to make the consumer comfortable." He now claims an inventory of 30,000 certified diamonds and offers a choice of 70 engagement ring settings. Blue Nile, still privately held, passed its fifth profitable quarter in August 2003, and will record an estimated $\$ 125$ million in sales for the year, a $74 \%$ increase over 2002 .

\section{SYNTHETICS AND SIMULANTS}

Natural versus hydrothermal synthetic Russian red beryl: Chemical composition and spectroscopic measurements. M. Fumagalli, L. Prosperi, A. Pavese, and S. Bordiga, Journal of Gemmology, Vol. 28, No. 5, 2003, pp. 291-301.

Six hydrothermal synthetic red beryls produced in Russia were compared to two natural specimens from Utah to determine the most reliable chemical-physical parameters to distinguish them. The results of standard gemological testing on all eight samples indicated that R.I., S.G., and fluorescence are not diagnostic. However, magnification revealed that inhomogeneous growth structures, described as "angular" or "chevron-like," only occurred in the synthetic samples and therefore are diagnostic. The synthetics also had much stronger pleochroism.

Chemical analysis was also useful for separating synthetic from natural red beryl. The former will likely contain $\mathrm{Co}$, whereas the latter will contain characteristic (and generally higher) amounts of $\mathrm{K}, \mathrm{Na}, \mathrm{Mn}, \mathrm{Cs}$, and $\mathrm{Zn}$. Infrared spectroscopy revealed a significant presence of water in synthetic red beryl. Raman spectroscopy showed additional peaks above $2000 \mathrm{~cm}^{-1}$ in the synthetics compared to the natural specimens, as well as a broad hump over the interval $3500-1500 \mathrm{~cm}^{-1}$ that is attributed to significant fluorescence of synthetic red beryl to the 1064 nm laser.

WMM

A note on sky-blue glass with needle-like inclusions. J. M. Duroc-Danner, Journal of Gemmology, Vol. 28, No. 5, 2003, pp. 280-282.

A convincing glass imitation is described that weighed $2.44 \mathrm{ct}$ and was "sky" blue. The sample had a vitreous luster, with R.I. $=1.593$ and S.G. $=3.28$. The absorption spectrum showed a band at 400-420 nm, with three fine lines at 640,660 , and $670 \mathrm{~nm}$. It fluoresced a strong chalky greenish yellow to short-wave and a moderate orange to long-wave UV radiation. Except for the blue color, these properties are similar to those of ekanite (which is typically green). Further testing revealed no radioactivity; ekanite is typically strongly radioactive.

The sample contained numerous needle-like inclu- 
sions intersecting in different planes and a few pinpoint inclusions. Careful examination revealed that the needles were most probably hollow canals similar to those used in fiber optics; this characteristic could easily be mistaken as natural on quick inspection.

The physical and optical properties are consistent with those of leaded glass, which was confirmed by EDXRF analysis ( $\mathrm{Si}, \mathrm{Pb}, \mathrm{K}$, and $\mathrm{Ca}$ were the main constituents). It was concluded that this glass simulant with its needle-like inclusions was deliberately cut to fool a potential buyer into thinking that it was a natural gem.

CT

\section{TREATMENTS}

Behavior of Brazilian Imperial topaz at high temperature. A. C. S. Sabioni, G. M. da Costa, J. M. Dereppe, C. Moreaux, and C. M. Ferreira, Journal of Gemmology, Vol. 28, No. 5, 2003, pp. 283-290.

The effect of heat treatment on the structure and composition of orange Imperial topaz from the Capão mine, Ouro Preto, Brazil, is reported. To insure consistency, the studied samples were taken from a single large crystal. The samples were subjected to a range of temperatures $\left(0-1,400^{\circ} \mathrm{C}\right)$ for varying lengths of time (1-23 hours). Variations in structure were detected by X-ray diffraction, and the abundances of $\mathrm{H}$ and $\mathrm{F}$ were measured by nuclear magnetic resonance.

The results showed that the samples were structurally and chemically stable below $1,000^{\circ} \mathrm{C}$, although optical properties did change; on heating, the orange color changed to pink at approximately $600^{\circ} \mathrm{C}$ and then became colorless at $900^{\circ} \mathrm{C}$ due to destruction of the color centers. Above $1,100^{\circ} \mathrm{C}$, the topaz began to change both chemically, by losing $\mathrm{H}, \mathrm{F}$ (and some Si), and structurally. At approximately $1,300^{\circ} \mathrm{C}$, it was completely transformed to opaque white mullite $\left(\mathrm{Al}_{6} \mathrm{Si}_{2} \mathrm{O}_{13}\right)$.

$W M M$

\section{MISCELLANEOUS}

The billionaire who cracked De Beers. P. Berman and L. Goldman, Forbes, September 15, 2003, pp. 109-116.

Lev Leviev is a Russian émigré living in Israel who has built the world's largest diamond business outside of the De Beers Diamond Trading Company (DTC). In recent years, he has challenged De Beers's exclusive marketing deals in Russia and Angola, and shaken the traditional structure of the diamond business.

Leviev was born in Tashkent, Uzbekistan, to a family that defied the communist ban on religion by following the Chabad-Lubavitch movement of Judaism. His family emigrated to Israel in 1971. Six years later, Leviev opened his own cutting factory and, avoiding the speculative boom in diamonds that gripped the market shortly thereafter, managed to weather the crisis of 1981-82 in good shape. Leviev became a DTC sightholder in 1987, and two years later was invited by Russia's state-run diamond operation to set up diamond-cutting operations.

Leviev kept his connections to Russia's diamond hierarchy and cultivated relationships with top government officials including Mikhail Gorbachev, Boris Yeltsin, and Vladimir Putin. By 1995, Leviev had managed to secure supplies of rough from Gokhran, the country's diamond stockpile. This resulted in De Beers ending his sight. Leviev was believed to be the major conduit through which the Russian government sold off much of its stockpile (estimated to be as much as $\$ 12$ billion) in the mid1990s. Leviev also moved into civil-war-torn Angola after De Beers stopped buying there because the government could not certify the legitimate origins of its diamonds, and then moved on to offshore mining operations in Namibia. After building his diamond business internationally, Leviev has since entered real estate development, and has engaged in numerous philanthropic activities in his native country and Israel.

$R S$

Birefringence vs. double refraction divergence. R. Cartier, Journal of Gemmology, Vol. 28, No. 4, 2002, pp. 223-226.

The author discusses a terminology problem often encountered in gemology, but not always recognized: use of the phrase "double refraction" (or "DR") when the concept of birefringence is actually what is intended. The latter is a property of a medium that has two simultaneous differing optical densities that result in two distinct refractive indices (i.e., different velocities for light traveling in the medium). As a quantifiable property, it has come to mean the numerical difference between two measured refractive index readings for the same wavelength of light. In contrast, refraction is the behavior of light when it goes from one medium into another and changes its direction of travel. This change in direction is not only dependent on the refractive index value(s), but also on the angle of incidence of the light.

The author presents a summary table for uniaxial and biaxial materials for normal-incident light traveling parallel, perpendicular, or at some intermediate angle to the optic axis (or axes), and indicates when both the birefringence and what he terms the "double refraction diver-

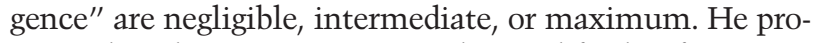
poses that the contraction " $\mathrm{BI}^{\prime}$ be used for birefringence, and "DD" be used for double refraction divergence. He also recommends that the use of "DR" for double refraction be discontinued, because for too long it has been confused with birefringence.

JES

Doubling of images in gemstones. D. B. Sturman and M. E. Back, Journal of Gemmology, Vol. 28, No. 4, 2002, pp. 210-222.

Doubling of images (e.g., facet junctions) is a phenomenon that is seen in some anisotropic gemstones and can down- 
grade their appearance. This article presents an analysis of this doubling effect for both uniaxial and biaxial gem minerals, for instances when light exiting the gemstone is parallel, perpendicular, or at some intermediate angle to the mineral's optic axis (or axes). Maximum doubling occurs when the exiting light travels at an angle of about $45^{\circ}$ to the optic axis (as a result of this light being split into two component rays with different refractive indices, vibration directions, and directions of travel). The visual extent of doubling increases with the angular separation of the two component rays and thus the size of the gemstone. Diagrams are presented which allow the maximum possible separation of images to be determined for particular minerals, and for the effect of the angle between the optic axis and a line perpendicular to the table facet. The mathematical basis of these diagrams is presented in two appendices.

"Hot money" and daring consumption in a northern Malagasy sapphire-mining town. A. Walsh, American Ethnologist, Vol. 30, No. 2, 2003, pp. 290-305.

Sapphire deposits were found near the town of Ambondromifehy in northern Madagascar in 1996. Within two years, the sleepy village of 400 was transformed into a boom town of about 14,000. Lured by the prospect of easy money from sapphire digging, many young men flocked to the town, causing the boom-town plague of crime, disease, and inflated living costs. What separates Ambondromifehy from some other boom towns is that miners tend to work for themselves instead of for companies or claim holders.

Some three-fourths of the town's inhabitants are miners, who dig pits in the soil and scour cave bottoms (where sediments were trapped) for sapphires. Since the deposits have no adequate water source, the miners must carry their diggings in sacks to an area near the town for sieving. More-experienced miners often help newcomers with details such as where to dig, how to negotiate prices, and how to avoid the local police. This is in keeping with Malagasy hospitality traditions. Miners also rely on diviners to reveal digging sites, and avoid certain "medicines" that might repel sapphires.

Because few miners consider making Ambondromifehy their permanent home, the town remains a jumble of makeshift buildings. Miners who don't spend their money on flashy consumables send it back to their families, leaving no local investment in wells, houses, or cattle. RS

Jurisdiction over offshore diamond mining. L. E. Moller. Journal of Energy « Natural Resources Law, Vol. 21, No. 2, 2003, pp. 168-185.

This article reviews the various laws under which the government of Namibia controls the mining of diamonds off its coast. While the government exerts full mineral rights over deposits within its territorial waters, a potential prob- lem may arise with mining vessels that are registered under some other national flag, especially South Africa, where most of the mining ships are registered. In addition, Article 73 of the UN Convention, which allows states to exercise jurisdiction over fishing vessels in their waters, does not specifically cover mining and exploration ships. However, other Articles of the UN Convention (56, 77, 80, and 81) grant Namibia the sovereign right to all exploration activities, jurisdiction over resources within its territorial waters, and the sole right to authorize exploration and mining within those waters. Finally, there is no agreed-upon maritime boundary between Namibia and South Africa.

Namibia's Minerals Act and Diamond Act allow its courts to try any offense committed in its territorial waters, but the country does not have adequate law enforcement and monitoring facilities to check diamondmining vessels.

The study recommends that the government cooperate more closely with South Africa for mutual assistance in monitoring mining activities and that it thoroughly review its law enforcement activities to safeguard its national interests, in view of its UN-sanctioned rights.

Safeguarding rough diamonds. R. Corfield, Rough Diamond Review, No. 1, June 2003, pp. 32, 35-37.

Theft and trafficking in stolen diamonds is known as Illicit Diamond Buying (I.D.B.), and it occurs almost anywhere diamonds are mined or processed. The United Nations estimates $15 \%$ of the rough (non-conflict) diamond trade is I.D.B. The extent of theft at the mining stage is difficult to establish, because there is no way to determine what quantity of diamonds should have been recovered. Thefts also occur at all stages of diamond processing and may involve individuals ranging from plant maintenance workers to polishers and sorters. Many sophisticated methods have been used to steal diamonds; these include using carrier pigeons and hiding the rough in self-inflicted wounds. Collusive thefts are the most serious in terms of losses; these can involve people from security guards to those in senior level and accounting positions, and can involve changing records and altering production data.

The approach to security by diamond producers must be multidisciplinary, and must involve senior management to implement a proactive and technically focused program that recognizes unusual employee behavior and temptation. Practical solutions include automation, which provides less human contact at the mining and processing stages, and reliable audits of all phases of plant operations. Exchanging information with other mine producers, and legislation that favors security measures, can also be helpful in curbing thefts. Ron Stumman 